touching farewell to one whose whole life had been unselfishly devoted to the promotion of good works. The large attendance marked the respect in which the deceased was beld, and the difference of classes and opinions represented pointed to the variety of the work in which he had been engaged.

SIR WILLIAM HICKS FARRINGTON, BART., M.D.ST. AND., M R.C.S. ENG., L.S.A.

SIR William HICKS FARRINGTON, who was the fifth baronet of his line, was the elder surviving son of the fourth baronet, Sir Henry Anthony Farrington, who died in 1888. Sir William Farrington, who was born in 1838, was educated at the King 's School, Ottery St. Mary, and at St. Bartholomew's Hospital, where he held the offices of house surgeon and resident accoucheur. He became a Member of the Royal College of Surgeons of England in 1859 and a Licentiate of the Society of Apothecaries in 1860. Besides his hospital appointments be held those of resident medical officer to the London Fever Hospital and of assistant surgeon to H.M. Convict Prison at Gibraltar. He was afterwards in practice at Penshurst, Kent. He is succeeded in the title by his son Henry Anthony Farrington, who was born in 1871.

CHARLES HARWOOD, M.D., L.R.C.S. KDIN.

DR. CHARLES HARWOOD of Hemington, Leicestershire, died very suddenly on Jan. 3rd while engaged on professional business at some distance from his home. On Jan. 2nd he was apparently in good health and spirits, and on Jan. 3rd he drove to Melbourne, a small town in the adjoining county of Derby, where he was seized with jllness while in the house of a member of the board of guardians and expired almost immediately. Dr. Harwood was the son of a medical practitioner in Derby and received his professional education in Edinburgh, where he took the degree of M.D. and the diploma of L.R.C.S. in 1850. At the time of his death he held the appointments of medical officer of health of the Shardlow, Stapleford, and Castle Donington rural district conncils; he had also formerly boen medical officer of health of the borough of Derby, surgeon to the Derby Dispensary, and surgeon-major to the Derbyshire Regiment. Dr. Harwood was well known and much respected in the Castle Donington district, where he had practised for many years. He has left a widow and family for whom much sympathy is felt.

Deates of Eminent Forigian Medical Men.-The deaths of the following eminent foreign medical men are announced :-Dr. Horace Tracy Hanks, Professor of Gynæcology in the Post-Graduate Medical School, New York.-Dr. R. J. Curtiss, formerly Professor of Bacteriology in the College of Physicians and Surgeons, Chicago.-Dr. Berne, Honorary Professor in the Medical Faculty of the University of Lyons.

\section{THE WAR IN SOUTH AFRICA.}

\section{THE $X$ RAYS IN SOUTH AFRICA.}

BY JoHN HaLL-EDW ARDS, L.R.C.P. EdIN.

SURGEON RADIOGRAPHER TO THE GENERAL HOSPITAL, BIRMINGHAM, AND TO THE IMPERTAL YEOMANRT HOSPITAL, DEELFONTEIN, SOUTH AFRTCA.

SOME time before leaving England and long before I had any idea that my services would be required in South Africa $I$ advocated, through the medium of the medical press, a more extended application of the $x$ rays to military surgery. Nine months' experience here has proved that they are much more useful than I even ventured to predict and that in their usefulness they stand only second in importance to aseptic surgery. As my suggestions and predictions then were based purely upon work carried on in civil practice, with but a very superficial knowledge of the actualities of war, I am doubly pleased to record that $\mathrm{my}$ hopes have been more than realised and that excellent surgery has been the outcome of the work done here.

Before being appointed on the staff of the Imperial Yeomanry Hospital I made repeated applications to the War Office, always with the same result-viz., a sheet of blue paper informing me that there was no call for $x$-ray experts in South Africa. On one occasion I had a personal interview with an official at the War Office who told me that for several reasons they could not send me out. In the first place, there was very little useful work to be done; in the second place, that there were already out many men capable of undertaking the work; and lastly, that they could not afford to send me out, however much they might wish to do so. At the same time, I was shown a cablegram. from South Africa demanding the immediate presence of eight men with a sufficient knowledge of electricity and photography to enable them to help the experts (?) already sent out and to repair broken-down apparatus-or, in other words, to do the work for which someone else would get the credit. How the arrangement has worked I am not entirely in a position to say, but from what I have heard the results which were produced bave not fulfilled the anticipations and expectations of some of the surgeons, and judging from the several cases sent to $u$ s where others have failed to find bullets (after the application of the $x$ rays) I should imagine that the experiment has not altogether proved a success. An eminent consulting surgeon who visited our hospital amused me by asking if localisation in my hands had proved a success and I learned from him that in some of the base hospitals the surgeons had been greatly misled by it. On wy informing him that a properly carriedout localisation was absolutely accurate and certain he expressed great surprise, proving that he had received some information to the contrary. Granting that the procedure of localisation has been properly carried out, if there is any mistake it is due to want of knowledge on the part of the $\mathrm{x}$-ray operator, who must, if his deductions are to be of any value, have had considerable experience, combined with a knowledge of anatomy and surgery. The assistants sent out by the War Office have in most instances become masters, either from force of circumstances or from a lack of interest on the part of those whom they were sent to assist. I may mention that the experts (?) themselves had in many instances but a few days' training prior to their proceeding to the seat of war. And the work done by their (socalled) assistants may be, and in all probability is, good, but inasmuch as they can have had but a very limited experience, and as in most cases they have no knowledge of anatomy or surgery, the operative surgeons cannot accept any suggestion from them, hence failure results. As an example of the way in which an excellent radiograph and localisation may be misleading I would like to quote the following case which was brought to my notice at a large hospital at Pretoria. A patient having a bullet in his thigh was radiographed and its position was marked on the limb. The surgeon cut down upon the spot indicated but failed to find it; after a prolonged search it was eventually found two inches higher up the limb. It was subsequently found that the spot indicated upon the skin of the patient had been arrived at from measurements made upon the negative. As in every negative there is a small amount of distortion, and in some a very considerable amount, measurements made in this manner are always unreliable and grave consequences are almost certain to follow such an unscientific proceeding.

Notwithstanding the fact that the penetrative power of modern small-bore projectiles is such that at all ranges up to 1500 yards under ordinary circumstances they pass tbrough the tissues without doing any considerable amount of harm, there is in a large war such as we are at present engaged in plenty of work for the surgeon radiographer. Out of the 200 cases which up to the present have come under my notice over 60 bullets or portions of bullets or shells have been found and accurately located. In 54 of these cases the foreign bodies have been removed and in no case has the surgeon failed to find what he looked for. In the remaining cases no operation has been performed, it being thought best-for a variety of reasons it is not necessary for me to mention here-at any rate for the present to leave them undisturbed. Of the remaining 140 cases most of them were examined for the purpose of ascertaining the amount of injury sustained by bone after the passage of a bullet through it, and in a few no foreign body was found, although its presence was suspected.

These figures plainly show that at any rate one of the assertions made by the authorities at home has no foundation in fact and that they formed erroneous opinions, founded on inezperience, as to the numerous accidents which tend to diminish the penetrative power of modern projectiles. 
Whilst the capability of the $x$ rays of discovering and accurately locating bullets was not for one moment questioned, the number of bullets which experience has shown are for one reason or another retained in the tissues was vastly under-estimated. At any range up to 1000 yards a Mauser or Lee-Metford bullet will pass through the densest bony structures of the human body, granting that a full charge of cordite has been used, that the bullet has been unimpeded in its flight, and that the cupro-nickel casing is complete. It occasionally happens, however, that a full charge of cordite has for some reason or another not been used. It is still more common for a bullet to strike some hard substance before finding its final billet, and I have good reasons for suspecting that most of those which I have localised come under this category. A ricochet bullet is by far the most dangerous to meet, and the Boers are so far aware of this fact that they prefer to fire low, at the ground, in front of our troops. A ricochet bullet is especially dangerous for three reasons. In the first place, even if it falls upon soft ground and is not deformed, its penetrative power is so greatly diminished that it is likely to be retained in the tissues if it finds a billet; secondly, if it strikes a hard substance it is so altered in shape that serious tearings of the tissues and splintering of bones are certain to accrue ; and thirdly, without being greatly altered in shape it may have imparted to it an amount of spin which produces serions results. A spinning bullet is one of the most dangerous of missiles and the amount of damage it is capable of inflicting depends to a very great extent upon the rate of spin; this may be so slow that the entrance wound may present all the characteristics of an ordinary entrance wound, or it may be so fast as to produce a large irregular wound, such as one would expect to have been caused by a piece of shell. Considerable difference of opinion exists as to the possibility of an uninjured Lee-Metford or Mauser bullet being flattened against bone when fired directly into the tissues. From my experience I am of opinion that under such conditions no flattening of the bullet is possible, and that in all cases where a whole bullet is found to be deformed it has struck some substance harder than bone before entering the body.

Qaite apart from the finding and localising of bullets, most excellent and useful work is to be done in radiographing all bullet and shell injuries to bone, and many useful observations will be made by the careful examination of the resulting pictures. Our knowledge of the amount and character of injury which under varying circumstances can be done by a bullet, is so small and incomplete that many new facts should come to light as the result of the work done during the present war, and had the x-ray work been as carefully carried out as its importance warrants one of the greatest advances ever made in military surgery would have been placed to our credit. That the $x$ rays have not been given a fair chance $I$ am in a position to prove. Some hospitals have been supplied with excellent apparatus but no one to work it, whilst in others there is no apparatus, and in a few, whilst having the apparatus, it is placed in such incompetent hands as to prove rather a source of danger than one of the most useful adjuncts. Many patients have been sent home with bullets still in their tissues which should have been removed, whilst others have suffered weeks of pain which should have been relieved in a few hours.

If the $x$ rays are to prove of full use in future wars one of the first steps to be taken by our War Office must be the organisation of a complete $x$ ray department, where the methods of procedure will be properly taught, experiments made, and apparatus designed and manufactured, with a full knowledge of the requirements of military surgery under all conditions and circumstances. The apparatus placed at my disposal is as complete and efficient as could be purchased. Nevertheless, it is by no means perfect, and had I been placed in less fortunate circumstances I should several times have been landed in difficulties. Experience has convinced me that much time and thought will have to be expended before our apparatus can even be said to be as perfect as our present knowledge will allow, and as the science is certain to progress there is a large field open to experiment. It would be greatly to the advantage of the Army Medical Department if experiments were carried out under their own control. The cost would be but a trifle compared with the great advantages which would be reaped not only to military but to civil surgery.
In future wars each base hospital must have its surgeonradiographer, and in addition there must be a number of experts unattached who with portable apparatus can be sent anywhere and everywhere as circumstances may demand. Several lives and limbs would have been saved during the present war-for instance, at the relief of Mafeking-had an expert been within reasonable call. Inasmuch as radiography has been recognised as a legitimate branch of medicine none but qualified experts should be employed, and apart from this, and for reasons which I have already mentioned, this is absolutely necessary if the best results are to be sought after. Recent events at home have shown that the $x$ rays in inexperienced hands are a source of great public denger, and it is to be hoped that steps will be taken to place it beyond the power of the novice to expose his friends or enemies to danger.

In this letter I bave purposely refrained from entering into details of any of the many interesting cases which have passed through my hands; I hope, however, to publish some of these on my return home.

Deelfontein, South Africa.

\section{VITAL STATISTICS.}

\section{HWALTH OF ENGLISH TOWNS}

IN 33 of the largest English towns 7329 births and 3964 deaths were registered during the week ending Jan. 5th. The annual rate of mortality in these towns, which had been 16.1 and 16.9 per 1000 in the two preceding weeks, further rose last week to $17 \cdot 5$. In London the rate was $17 \cdot 8$ per 1000 , while it averaged $17 \cdot 3$ in the 32 large provincial towns. The lowest death-rates in these towns were 8.6 in Derby, 10.5 in Oroydon, 11.2 in Norwich, and 12.0 in Portsmouth; the highest rates were 21.0 in Birkenhead, 21.4 in Sheffield, 21.5 in Manchester, and 22.5 in Liverpool. The 3964 deaths in the 33 towns last week included 323 which were referred to the principal zymotic diseases, against 351 anã 334 in the two preceding weeks; of these 79 resulted from diphtheria, 71 from whooping-cough, 56 from measles, 47 from "fever" (principally enteric), 37 from diarrhoea, and 33 from scarlet fever. No death from any of these diseases occurred last week in Huddersfield; in the other towns they caused the lowest death-rates in Cardiff, Burnley, Hull, and Newcastle, and the highest rates in Wolverhampton, Salford, Blackburn, and Sheffield. The greatest mortality from measles occurred in Wolverhampton and in Blackburn; and from whooping-cough in Birkenhead and Sheffield. The mortality from scarlet fever and from "fever" showed no marked excess in any of the large towns. The 79 deaths from diphtheria included 24 in London, eight in West Ham, eight in Sheffield, seren in Leicester, and five in Bristol. No fatal case of small-pox was registered last week in any of the 33 towns, and only one smallpox patient remained under treatment in the Metropolitan Asylums hospitals on Saturday last, Jan. 5th. The number of scarlet fever patients in these rospitals and in the London Fever Hospital at the end of the week was 2390 , against 2477 and 2535 on the two preceding Saturdays; 163 new cases were admitted during the week, against 255,218 , and 167 in the three preceding weeks. The deaths referred to diseases of the respiratory organs in London, which had been 306 and 325 in the two preceding weeks, further rose last week to 330 , but were 376 below the corrected average. The causes of 49 , or $1 \cdot 3$ per cent., of the deaths in the 33 towns last week were not certified either by a registered medical practitioner or by a coroner, All the causes of death were duly certified in Nottingham, Bradford, Leeds, and in 12 other smaller towns; the largest proportions of uncertified deaths were registered in Liverpool, Preston, Hnll, and Gateshead.

HEALTH OF SCOTCH TOWNS.

The annual rate of mortality in the eight Scotch towns, which had been 18.2 and 20.6 per 1000 in the two preceding weeks, declined again to $19^{\circ} 2$ during the week ending Jan. 5th, but showed an excess of $1 \cdot 7$ per 1000 over the mean rate during the same period in the 33 large English towns. The rates in the eight Scotch towns ranged from 14.4 in Paisley and 15.7 in Leith to 21.5 in Flinburgh and in Dundee and 22.4 in Greenock. The 602 deaths in these 